\title{
Ethnobotanical Study Of Medicinal Plants In The Fight Against Buruli Ulcer In The Maritime Region Of Togo
}

\section{Tchalare Kondi Makagni, Msc}

Laboratoire des Sciences Biomédicales, Alimentaires et de Santé Environnementale (LaSBASE), Ecole Supérieure des Techniques Biologiques et Alimentaires (ESTBA), Université de Lomé, Centre Hospitalier Régional de Tsévié, Centre National de Référence et de

Traitement de l'Ulcère de Buruli, Togo

\section{Efui Holaly Gbekley, PhD}

Laboratoire des Sciences Biomédicales, Alimentaires et de Santé Environnementale (LaSBASE), Ecole Supérieure des Techniques

Biologiques et Alimentaires (ESTBA), Université de Lomé, Togo Laboratoire de Biologie, de Phytochimie, de Toxicologie, de Pharmacologie et d'Agro-alimentaires ( Bio-PhyToPharmA), Lomé, Togo

\author{
Yao Hoekou, PhD \\ Maman Issaka, PhD \\ Passimna Pissang, PhD \\ Kodjovi Agbodeka, PhD \\ Tchadjobo Tchacondo, Professor
}

Laboratoire des Sciences Biomédicales, Alimentaires et de Santé

Environnementale (LaSBASE), Ecole Supérieure des Techniques

Biologiques et Alimentaires (ESTBA), Université de Lomé, Togo

Simplice Damintoti Karou, Professor

Laboratoire de Microbiologie et de Contrôle de Qualité des Denrées

Alimentaires (LAMICODA), Université de Lomé, Togo

\section{Komlan Batawila, Professor}

Laboratoire de Botanique et Ecologie Végétale, Faculté des Sciences (FDS),

Université de Lomé, Togo

Doi:10.19044/esj.2020.v16n27p239 URL:http://dx.doi.org/10.19044/esj.2020.v16n27p239

Abstract

Background: In Togo, few data are available on the traditional treatment of Buruli ulcer, so this study aim to inventory and identify the plants 
and recipes included in the herbal medicines in the maritime region where this disease is more common. Method: The methodology was based on ethnobotanical semi-structural individual interviews of 16 traditional healers in the maritime region. The Data were collected and analyzed in Microsoft excel 2013. Results: 10 of the traditional healers were male and the average age of all the respondents was $42.31 \pm 4.24$ years. A total of 27 plant species belonging to 20 families were identified. The most represented families were: Caesalpinaceae with 3 species, Euphorbiaceae, Apocynaceae, Asteraceae, Sapindaceae and Annonaceae with 2 species each. In the preparation methods, the decoction is the most used (37\%), followed by the black powdered incorporated in an ointment (24\%), the maceration (15\%), the infusion $(12 \%)$, the spraying $(6 \%)$ and poultices $(6 \%)$. These modes of preparation, were administered mainly externally by massage, disinfection of the lesion and orally. The most used parts of the plants were leaves $(48 \%)$, roots $(21 \%)$, and bark (10\%). The species with the highest frequency of use were Blighia sapida KD Koenig, Amaranthus spinosus L, Ocimum canum Sims, Piliostigma thonningii (Schum.) Milne-Redh, Aloe verra L, Anacardium occidentale L, Paullinia pinnata L and Xylopia aethiopica (Dunal) A.Rich. Conclusion: By highlighting these plant species of interest, this study has an applicability in therapeutic innovation. It can contribute to the chemical, pharmacological and clinical evaluations of their molecules leading to development of phytomedicines to produce new drugs to strengthen the already existing therapeutic arsenal.

Keywords: Buruli ulcer, Plants, Traditional treatment, Togo Maritime Region

\section{Introduction}

Buruli Ulcer (BU) is a skin disease caused by a mycobacterium called Mycobacterium ulcerans. The outbreaks are geographically almost always circumscribed around an aquatic ecosystem (river, artificial or natural lake, marsh area, irrigation system) (Maman et al, 2018; Portaels et al, 2008). In 2019, Buruli ulcer has been identified by the World Health Organization (WHO) in more than 30 countries on several continents (Africa, America, Asia, and Oceania) (OMS, 2019). In Africa 10 countries have reported cases of BU to WHO, including 4 in west Africa, notably Ghana, Côte d'Ivoire, Benin and Togo (WHO, 2019).

Buruli ulcer is part of the group of infectious diseases classified in neglected tropical diseases with a poorly known global prevalence and affecting mainly isolated rural African communities. This disease is the third most common mycobacterial infection after tuberculosis and leprosy (OMS, 2010). 
According to the WHO, Buruli ulcer begins with a painless nodule, plaque or œdema in the skin which, if left untreated, progresses to massive skin ulceration (OMS, 2012). Currently, only the specific antibiotic treatment, possibly associated or not with the surgery has a proven effectiveness. However, it can only be achieved in medical centers of affected countries with adequate technical facilities and specialized staff (OMS, 2012).

In Togo, the National Buruli Ulcer Control Program have confirmed more than 100 cases from 1996 to 2004. It was advised to patients in endemic areas for early detection of cases and immediate recourse to treatment centers as soon as possible at the first signs of the disease (Bretzel et al, 2011). The drug and surgical treatments are offered free of charge to patients, but there is the problem of side effects which can cause sequelae in children including liver, kidney, auditory and vestibular lesions. This treatment also seems to provide various mutilations, even amputations. Moreover, the surgical treatment, in combination or not with the drug treatment, presents satisfactory results, but also other constraints among which the long duration of hospitalizations and of treatment for many patients, mostly from rural areas (OMS, 2012; Houngbédji et al, 2011; Zhang et al, 2013). As in many African countries, patients prefer to start treatment with traditional medicines to any other form of care because of the lack of information on the cost of hospital care. The use of traditional medicines recipes in the treatment of Buruli ulcer is reported by several study in central and west Africa (Adjet et al, 2016; Bayaga et al, 2017; Johnson et al, 2004; Tsouh et al, 2015; Yemoa et al, 2008; Yemoa et al, 2015). The patients also resort to traditional treatment for cultural reasons because of the tradition which often requires consulting the traditional healer to know the cause of a disease. This treatment of Buruli ulcer is therefore the first resort available to these patients who are generally poor (Johnson et al, 2004). Despite the prevalence of this pathology in Togo, few works were conducted on the study of plants used traditionally and in first recourse by the populations of the maritime region, the main endemic center of this pathology in Togo. In order to explore and increase the potential in medicinal plants traditionally used against this pathology, the present study is proposed to identify the plants species and the recipes used by traditional healers in the treatment of BU in Maritime region of Togo.

\section{Methods}

\section{Study area and population}

This survey was conducted in the maritime region of Togo specifically in 17 villages in Zio and Yoto districts where a recent study focused on the risk factors for Mycobacterium ulcerans infection (Maman et al, 2018). These districts are in southern Togo $\left(6^{\circ} 30^{\prime} 0^{\prime \prime} \mathrm{N}\right.$ and $\left.1^{\circ} 19^{\prime} 60^{\prime \prime} \mathrm{E}\right)$. With an estimated population of $1,762,518$ in 2012, this region most burdens the disease with 
more than $85 \%$ of confirmed BU patients. The climate is tropical and humid with two rainy seasons and two dry seasons. Our survey was conducted among 16 traditional healers who treat Buruli ulcer. They were recruited from the list provided by the local coordinator of the traditional healers. This region has a good biological diversity in plant species (Rapport national sur la diversité biologique du Togo, 2014).

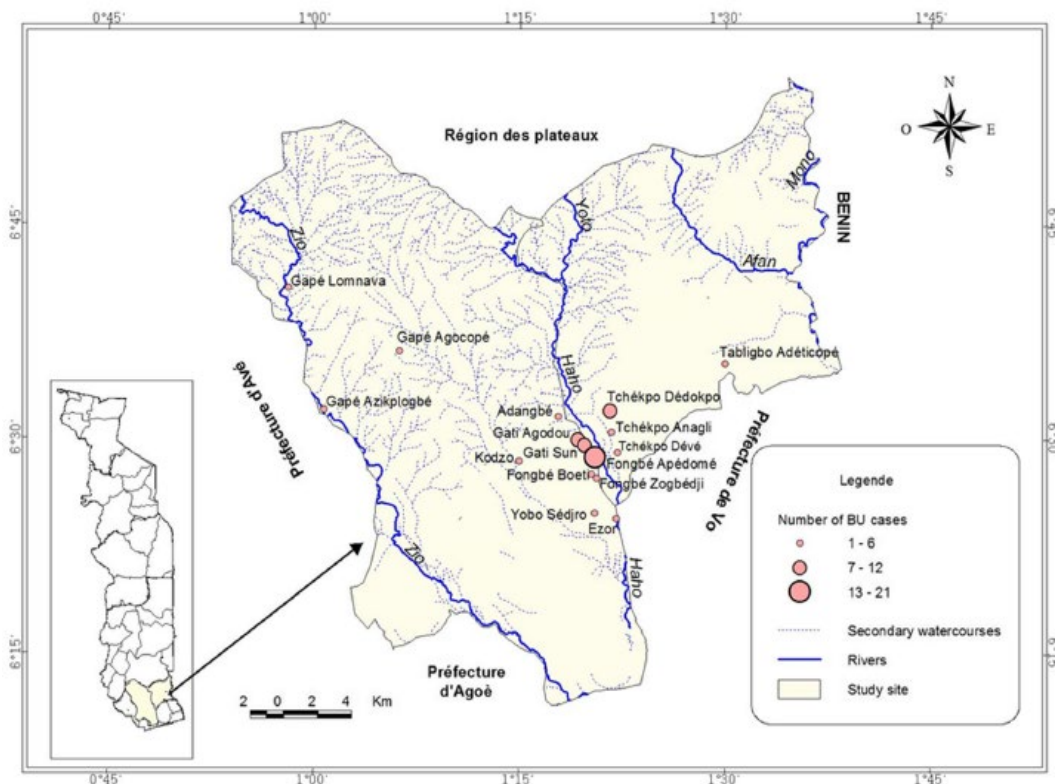

Figure 1: Maritime Region Map presenting villages surveyed, distribution of BU cases and hydrographic network (Maman et al, 2018)

\section{Study method}

This study is descriptive and qualitative. The information was collected from traditional healers based on direct observation and interviews. For this the technique of the individual interview with open questions is used. At a first contact, an appointment is requested in view of their availability for the interview. During the interview, data were collected on the diagnostic of the disease, the ingredients of the phytomedicines, their methods of preparations, their galenic form of presentation, the route of administration and the prohibitions during the treatment received by patients.

\section{Collect and identification of plants}

Some plants were immediately available in the habitat of traditional healers and were collected, for the others the collect was done with the help of the traditional healer using the local names. This identification was done with the approval of an expert in traditional medicine based on observation and the local names. Botanical identification continued at the herbarium of the Faculty of Science at the University of Lomé using the leaves and fruits of the various 
plants that we collected in the field and the local names. The botanist made the identification based on the specific characteristic of each species using Togo flora and the APG IV nomenclature.

\section{Data analysis}

The information collected from the survey is entered into the Microsoft Excel 2013 software and analyzed to make the calculations of the Rate of Use (RU) of the plants species. The calculation of the RU of each plant is made according to the study conducted by Yemoa in Benin (Yemoa et al, 2008):

$$
\mathrm{RU}=\frac{\text { Number of users of a given plant }}{\text { Total number of users }} \times 100
$$

High utilization rates were those between 40 and 60\%, averages between 15 and $39 \%$ and low values below $15 \%$.

\section{Results}

\section{Sociodemographic data of traditional healers}

This study enrolled 16 traditional healers from the Togo Maritime Region, 10 of which were male and 6 females. Their average age was $42.31 \pm$ 4.24 years with a minimum of 29 years and a maximum of 55 years. Table 1 summarizes the socio-demographic data of these traditional healers. Traditional healers have been divided into four age groups. The analysis of Table 2 shows that the majority of traditional healers was in the two age groups of 30 to 40 and 40 to 50 years of age. These two age groups represent more than $75 \%$ of respondents. About $50 \%$ of these traditional healers has reached primary school, 6.25\% have reached secondary level and $6.25 \%$ has reached university level. About the origin of their knowledge, $75 \%$ were introduced to the practice of traditional medicine within the family, while the others were initiated outside the family. The results of the survey also revealed that $56.25 \%$ of traditional healers practice traditional medicine in full time, while the others practice it as a secondary activity. Concerning the season and the time of harvesting plant organs, some traditional healer prefer the dry season and others the rainy season, but the factor that plays the most is the availability of plants for seasonal plants (Table 1).

Table 1: Sociodemographic data of traditional healers

\begin{tabular}{|c|c|c|c|c|c|c|c|}
\hline \multicolumn{2}{|c|}{ Sex } & \multicolumn{3}{|c|}{ Male } & \multicolumn{3}{|c|}{ Female } \\
\hline \multicolumn{2}{|c|}{$\mathrm{N}$} & \multicolumn{3}{|c|}{10} & \multicolumn{3}{|c|}{6} \\
\hline \multicolumn{2}{|c|}{$\%$} & \multicolumn{3}{|c|}{62.5} & \multicolumn{3}{|c|}{37.5} \\
\hline Age ranges & $<30$ years & [ 30-40 years] & \multicolumn{2}{|c|}{ ] 40-50 years] } & \multicolumn{3}{|c|}{$>50$ years } \\
\hline $\mathrm{N}$ & 01 & 06 & \multirow{2}{*}{\multicolumn{2}{|c|}{$\frac{07}{43.75}$}} & \multicolumn{3}{|c|}{02} \\
\hline$\%$ & 6.25 & 37.5 & & & & & 1,83 \\
\hline Schooling & Illiterate & \multicolumn{2}{|c|}{ Primary school } & & & \multicolumn{2}{|c|}{$\begin{array}{c}\text { Baccalaureat } \\
\text { e }\end{array}$} \\
\hline $\mathrm{N}$ & 06 & \multicolumn{2}{|c|}{08} & & & & 01 \\
\hline
\end{tabular}




\begin{tabular}{|c|c|c|c|c|}
\hline$\%$ & 37.5 & 50 & 6.25 & 6.25 \\
\hline Religion & Animist & Christian & Muslim & others \\
\hline $\mathrm{N}$ & 7 & 5 & 1 & 3 \\
\hline$\%$ & 43.75 & 31.25 & 6.25 & 18.75 \\
\hline $\begin{array}{l}\text { Origins of } \\
\text { Knowledge }\end{array}$ & $\begin{array}{c}\text { Exclusive Family } \\
\text { Heritage }\end{array}$ & \multicolumn{3}{|c|}{ Traditional Initiation } \\
\hline $\mathrm{N}$ & 12 & \multicolumn{3}{|c|}{4} \\
\hline$\%$ & 75 & \multicolumn{3}{|c|}{25} \\
\hline $\begin{array}{c}\text { Status of the } \\
\text { healer }\end{array}$ & Full time & \multicolumn{3}{|c|}{ Other activity } \\
\hline $\mathrm{N}$ & 9 & \multicolumn{3}{|c|}{7} \\
\hline$\%$ & 56.25 & \multicolumn{3}{|c|}{43.75} \\
\hline Season of picking & \multirow{2}{*}{\multicolumn{2}{|c|}{$\begin{array}{c}\text { Dry } \\
3\end{array}$}} & Rainy & All seasons \\
\hline $\mathrm{N}$ & & & & 6 \\
\hline$\%$ & 18.75 & \multicolumn{2}{|c|}{43.75} & 37.5 \\
\hline Time of day & Morning & Midday & Evening & $\begin{array}{c}\text { The whole } \\
\text { day }\end{array}$ \\
\hline $\mathrm{N}$ & 9 & 0 & 2 & 5 \\
\hline$\%$ & 56.25 & 0 & 12.5 & 31.25 \\
\hline
\end{tabular}

\section{Botanical characteristics and diversity of anti buruli plants}

In total, 27 species of plants belonging to 20 families have been identified in the treatment of Buruli ulcer in the maritime region of Togo. The most represented families were: Caesalpinaceae with 3 species, Euphorbiaceae, Apocynaceae, Asteraceae Sapindaceae and Annonaceae with 2 species each. The species with the highest frequency of use are Blighia sapida KD Koenig (56.25\%), Amaranthus spinosus L. (50.00\%), Ocimum canum Sims (50.00\%), Piliostigma thonningii (Schum.) Milne-Redh (50.00\%), Aloe verra L. (43.75\%), Anacardium occidentale L (43.75\%), Paullinia pinnata L. (43.75\%) and Xylopia aethiopica (Dunal) A.Rich $(43.75 \%)$ (Table2). The plant parts used to make herbal preparations are dry and fresh barks; dry and fresh leaves; roots, stems, fruits, and seeds of fruits. The Leaves were the most used part of plants (48\%) followed by roots $(21 \%)$, then barks $(10 \%)$, fruits $(7 \%)$, stems $(9 \%)$, flowers $(5 \%)$. These data are presented in Figure. 2, 3.

\section{Presentation form of phytomedicines and route of administration}

The preparation of the medicines employed several methods: decoction (37\%), followed by black powdered ointment $(24 \%)$, maceration $(15 \%)$, infusion (12\%), spraying (6\%) and poultices $(6 \%)$ (Figure 4$)$. The local administration was the predominant route of administration followed by oral administrations. Decoction, infusion, or maceration were reported as taken orally or used to wash or disinfect the wound while black powders ointment, spray, were applied on the ulcer as bandages. During the use of these recipes, 
the patients have to avoid the consumption of sugar, red oil, alcohol, and cassava. The global data of the survey is presented in Table 2.

Table 2: Plants used in the treatment of Buruli ulcer

\begin{tabular}{|c|c|c|c|c|c|c|}
\hline Families & Species & Codes & Local Names & $\begin{array}{l}\text { Used } \\
\text { parts }\end{array}$ & Galenic Forms & $\begin{array}{l}\mathbf{R U} \\
(\%)\end{array}$ \\
\hline Aloeaceae & Aloe verra $\mathrm{L}$. & - & Aloes & Leaves & $\begin{array}{l}\text { decoction and } \\
\text { black powder }\end{array}$ & 43.75 \\
\hline Anacardiaceae & $\begin{array}{l}\text { Anacardium } \\
\text { occidentale L. }\end{array}$ & TOGO15582 & Atchanti & $\begin{array}{l}\text { Bark, } \\
\text { leaves }\end{array}$ & $\begin{array}{l}\text { decoction and } \\
\text { black powder }\end{array}$ & 43.75 \\
\hline \multirow[t]{2}{*}{ Annonaceae } & $\begin{array}{l}\text { Xylopia aethiopica } \\
\text { (Dunal) A.Rich }\end{array}$ & TOGO15583 & Etso & Fruits & $\begin{array}{l}\text { Decoction, } \\
\text { infusion }\end{array}$ & 43.75 \\
\hline & $\begin{array}{l}\text { Citrus limon (L.) } \\
\text { Burm. }\end{array}$ & TOGO15584 & Donti & Fruits & $\begin{array}{c}\text { decoction and } \\
\text { maceration }\end{array}$ & 37.50 \\
\hline \multirow[t]{2}{*}{ Apocynaceae } & $\begin{array}{c}\text { Strophantus } \\
\text { sarmentosus DC }\end{array}$ & TOGO15586 & Amagan & $\begin{array}{c}\text { Leaves, } \\
\text { roots }\end{array}$ & $\begin{array}{l}\text { decoction, black } \\
\text { powder, poultice }\end{array}$ & 37.50 \\
\hline & $\begin{array}{c}\text { Strophanthus hispidus } \\
\text { DC }\end{array}$ & TOGO15372 & Aho & $\begin{array}{c}\text { Leaves, } \\
\text { roots }\end{array}$ & $\begin{array}{c}\text { decoction and } \\
\text { maceration }\end{array}$ & 37.50 \\
\hline \multirow[t]{2}{*}{ Asteraceae } & $\begin{array}{c}\text { Acanthospermum } \\
\text { hispidum D.C. }\end{array}$ & TOGO15585 & Ahunglunvi & Leaves & $\begin{array}{c}\text { decoction, black } \\
\text { powder }\end{array}$ & 37.50 \\
\hline & $\begin{array}{c}\text { Ageratum conyzoides } \\
\text { L. }\end{array}$ & TOGO15587 & Agbadjadjigbé & $\begin{array}{c}\text { Leaves, } \\
\text { roots }\end{array}$ & $\begin{array}{l}\text { Spray, infusion and } \\
\text { maceration }\end{array}$ & 25.00 \\
\hline Bignoniaceae & $\begin{array}{l}\text { Kigelia africana } \\
\text { (Lam.) Benth. }\end{array}$ & TOGO15590 & Gnakpekpe & Leaves & $\begin{array}{c}\text { spray, maceration, } \\
\text { decoction }\end{array}$ & 31.25 \\
\hline Bombacaceae & Adansonia digitata $\mathrm{L}$. & TOGO15588 & Adidoti & Bark & $\begin{array}{c}\text { Decoction, black } \\
\text { powder } \\
\text { Maceration } \\
\end{array}$ & 37.50 \\
\hline \multirow[t]{3}{*}{ Caesalpinaceae } & $\begin{array}{c}\text { Erythrophleum } \\
\text { suaveolens Guill. \& } \\
\text { Perr.) Brenan } \\
\end{array}$ & - & Atiuhia & $\begin{array}{l}\text { Bark, } \\
\text { roots }\end{array}$ & $\begin{array}{c}\text { Spray ,maceration, } \\
\text { decoction, } \\
\text { infusion } \\
\end{array}$ & 25.00 \\
\hline & $\begin{array}{c}\text { Caesalpinia } \\
\text { bonduc L. Roxb }\end{array}$ & TOGO15589 & Adikou & $\begin{array}{l}\text { Leaves, } \\
\text { fruit, } \\
\text { roots }\end{array}$ & $\begin{array}{l}\text { decoction, } \\
\text { maceration }\end{array}$ & 25.00 \\
\hline & Cassia alata L. Roxb & TOGO15591 & Patapa & $\begin{array}{l}\text { Leaves, } \\
\text { roots }\end{array}$ & $\begin{array}{l}\text { decoction ,black } \\
\text { powder, poultice } \\
\text { infusion }\end{array}$ & 37.50 \\
\hline Capparaceae & $\begin{array}{c}\text { Crateva religiosa } \mathrm{G} . \\
\text { Forst } \\
\end{array}$ & TOGO15592 & Awantagnizan & $\begin{array}{c}\text { Leaves, } \\
\text { roots }\end{array}$ & $\begin{array}{c}\text { Decoction, black } \\
\text { powder }\end{array}$ & 18.75 \\
\hline Caricaceae & Carica papaya $\mathrm{L}$. & TOGO15604 & Adubati & $\begin{array}{l}\text { Roots, } \\
\text { leaves }\end{array}$ & $\begin{array}{c}\text { Black powder, } \\
\text { decoction }\end{array}$ & 37.50 \\
\hline \multirow[t]{2}{*}{ Euphorbiaceae } & $\begin{array}{c}\text { Euphorbia hirta (L.) } \\
\text { Millsp }\end{array}$ & TOGO15593 & Anonsika & Leaves & $\begin{array}{c}\text { Decoction, black } \\
\text { powder }\end{array}$ & 37.50 \\
\hline & $\begin{array}{l}\text { Alchornea cordifolia } \\
\text { (L.) Millsp }\end{array}$ & TOGO15594 & Avlovlo & Leaves & $\begin{array}{c}\text { Decoction, } \\
\text { infusion } \\
\text { spray, maceration }\end{array}$ & 18.75 \\
\hline Fabaceae & $\begin{array}{l}\text { Piliostigma thonningii } \\
\text { (Schum.) Milne-Redh }\end{array}$ & TOGO15595 & Eklo & $\begin{array}{c}\text { Leaves, } \\
\text { stems }\end{array}$ & $\begin{array}{l}\text { Decoction ,black } \\
\text { powder, infusion }\end{array}$ & 50.00 \\
\hline Lamiaceae & Ocimum canum Sims & TOGO15596 & Ahamè & $\begin{array}{l}\text { Leaves, } \\
\text { stems, } \\
\text { Flowers }\end{array}$ & $\begin{array}{c}\text { Decoction, black } \\
\text { powder }\end{array}$ & 50.00 \\
\hline
\end{tabular}




\begin{tabular}{|c|c|c|c|c|c|c|}
\hline Meliaceae & $\begin{array}{l}\text { Azadirachta } \\
\text { indica A.Juss }\end{array}$ & TOGO15597 & Kiniti & $\begin{array}{l}\text { Leaves, } \\
\text { roots } \\
\text {,bark }\end{array}$ & $\begin{array}{l}\text { Decoction, } \\
\text { infusion black } \\
\text { powder, }\end{array}$ & 31.25 \\
\hline Musaceae & Musa paradisiaca L. & - & Amadanti & Trunk & $\begin{array}{l}\text { Decoction, } \\
\text { maceration }\end{array}$ & 31.25 \\
\hline Phyllanthacae & $\begin{array}{c}\text { Phyllanthus amarus } \\
\text { L. }\end{array}$ & TOGO15598 & Ehlivi & $\begin{array}{l}\text { Leaves, } \\
\text { stems }\end{array}$ & $\begin{array}{l}\text { Decoction, black } \\
\text { powder poultice }\end{array}$ & 37.50 \\
\hline Poaceae & Zea Mays L. & TOGO15599 & Ebli & Flowers & $\begin{array}{c}\text { Decoction, black } \\
\text { powder }\end{array}$ & 12.50 \\
\hline \multirow[t]{2}{*}{ Sapindaceae } & Paullinia pinnata $\mathrm{L}$. & TOGO15600 & Asiasion & Leaves & $\begin{array}{l}\text { Decoction, black } \\
\text { powder } \\
\text { Maceration, } \\
\text { infusion } \\
\end{array}$ & 43.75 \\
\hline & $\begin{array}{c}\text { Blighia sapida K. D. } \\
\text { Koenig }\end{array}$ & $\begin{array}{l}\text { TOGO156 } \\
01\end{array}$ & Atchanti & $\begin{array}{l}\text { Bark, } \\
\text { leaves }\end{array}$ & $\begin{array}{c}\text { Decoction, } \\
\text { Maceration, } \\
\text { Poultice } \\
\end{array}$ & 56.25 \\
\hline Verbenaceae & Tectona grandis L.f & TOGO 15602 & Tecti & Leaves & $\begin{array}{l}\text { Decoction, black } \\
\text { powder }\end{array}$ & 6.25 \\
\hline Amaranthaceae & $\begin{array}{c}\text { Amaranthus spinosus } \\
\text { L. }\end{array}$ & TOGO15603 & Aklantigbé & Leaves & decoction, poultice & 50.00 \\
\hline
\end{tabular}

RU: Rate of use

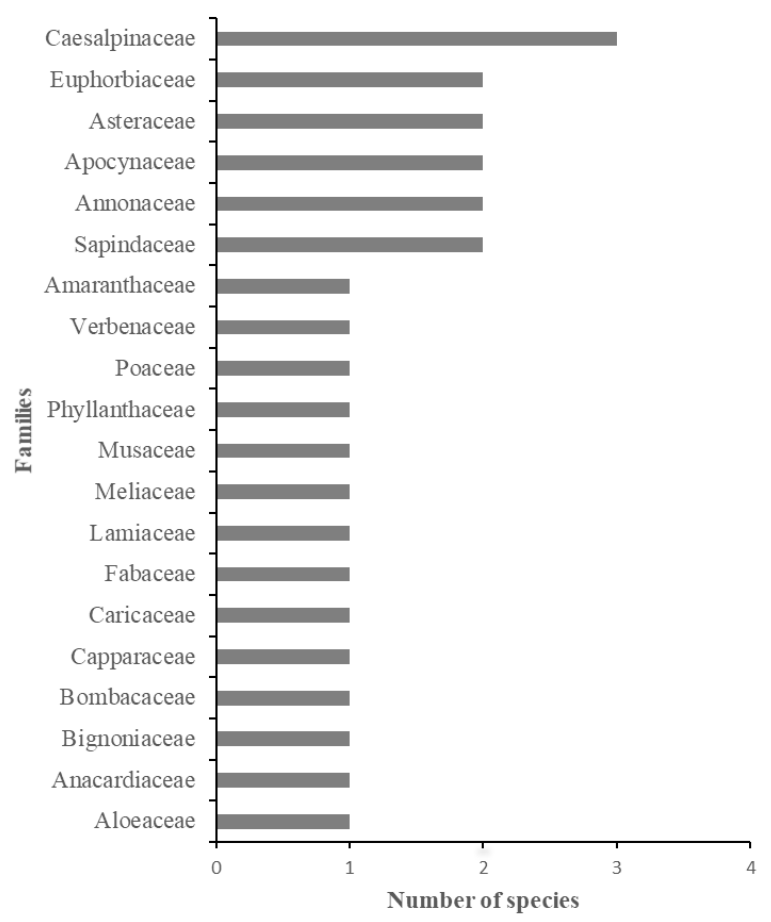

Figure 2: Anti buruli ulcer plant species distribution among families in Togo Maritime Region 


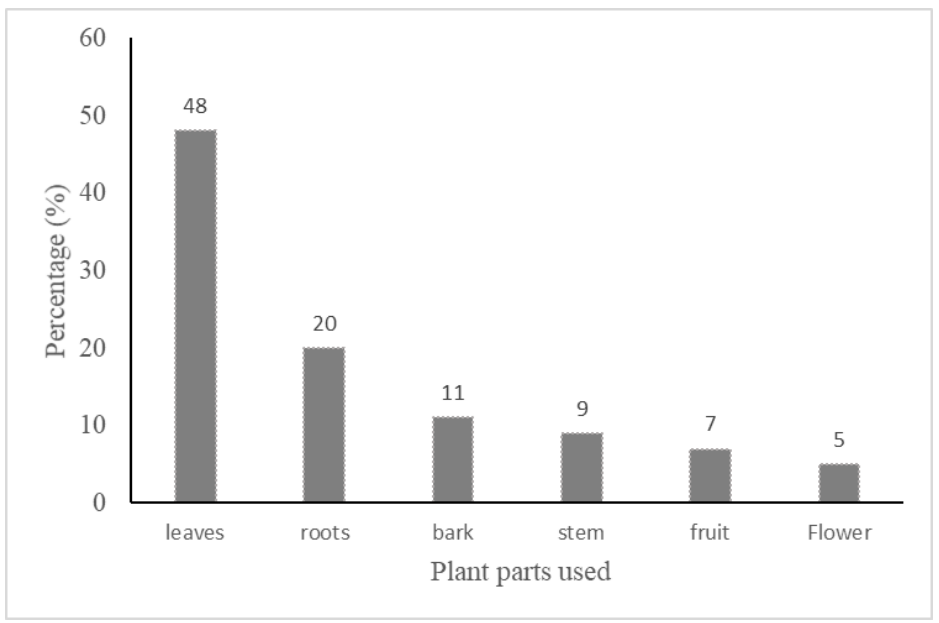

Figure 3: Frequency of plants part used

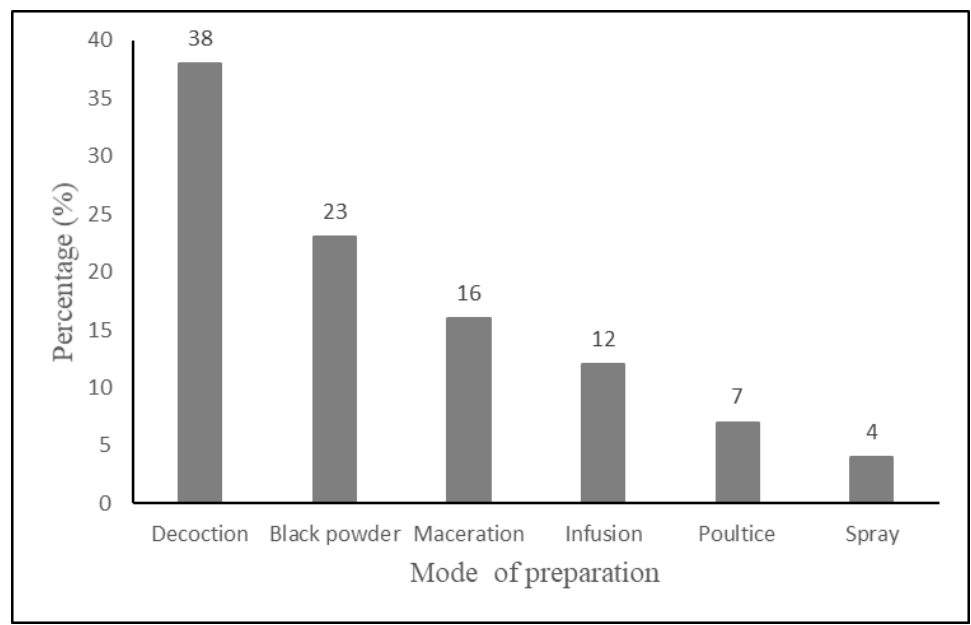

Figure 4: Repartition of forms of herbal preparations

\section{Discussion}

The present study was interested to the identification and ethnobotanical study of plants used in the traditional treatment of buruli ulcer in the maritime region of Togo. Our first observation is that traditional healers prospected were mostly male seniors. This profile of traditional healers in the Maritime Region of Togo is observed in most studies of this kind, confirming that the practice of traditional medicine is reserved for mature men (Aburjai et al 2007). The majority of people respondents were over 42 years of age. Indeed older people are expected to provide more reliable information, because they hold much of the ancestral knowledge (Lakouéténé et al, 2009). 
From the plants they use, 27 species have been identified. They are grouped into 20 families among which the more represented in species are Caesalpinaceae, Euphorbiaceae, Annonaceae, Apocynaceae and Asteraceae. The Euphobiaceae, Apocynaceae, Annonaceae families are also represented in studies conducted in tree West African countries (Tsouh et al, 2015). In 2016, Adjet et al conduct the same study in the Yamoussoukro health district and identified 15 plant species, four of which are found in our study: $X$. aethiopica, Musa paradisiaca L., P. thonningii. and C. papaya. In Benin, a similar study conducted in 2008 by Yemoah et al in Ouinhi commune, identified 49 plant species, five of which are found in our study: $X$. aethiopica, Strophanthus hispidus DC, Erythrophleum suaveolens Guill. \& Perr. Brenan, $P$. thonningii, $P$. pinnata. Among the most cited species in our study, previous work has demonstrated from various extracts the presence of molecules with biological properties in wounds healing. This is the case of $A$. vera which is a perennial plant widely used for the treatment of various diseases, including Buruli ulcer and extracts of its leaves showed a MIC of $40 \mu \mathrm{g} / \mathrm{ml}$ on $M$. ulcerans (Addo et al, 2007). Many of its chemicals have been identified such as carbohydrate polymers; glucomannans, phenolic compounds such as chromone and anthraquinone. Naturally, the gel is used for its wound healing potential because its high water content can keep the wound moist and promote the migration of epithelial cells. In addition, it has been suggested that the main carbohydrate, mannose-6-phosphate, plays an important role in the healing potential of wounds (Davis et al, 1994). Ocimum canum Sims contains rosmarinic acid which is known for its anti-inflammatory, antibacterial properties and the extracts of this plant are widely used in traditional pharmacopoeia (Tshilanda et al, 2016). The different parts of the western Anacardium species are known for their antimicrobial properties (Maia et al, 2000; Kubo et al, 2003; Gonçalves et al, 2012; Akinjogunla et al, 2012; Saidu et al, 2012; Marques et al, 1992; Laurens et al, 1982). The evaluation of the antimicrobial activity of ethanolic extracts of flowers, leaves, bark showed minimal bactericidal and fungicidal activities against: Streptococcus mutans, Lactobacillus acidophilus, Staphylococcus aureus, MRSA, Enterococcus faecalis, Streptococcus pyogenes, Pseudomonas aeruginosa, Proteus mirabilis, Escherichia coli, Klebsiella pneumoniae, Helicobacter pylori, Candida albicans and Candida tropicalis. An antioxidant activity was also observed on the extracts (Silva et al, 2016). X. aethiopica is a plant that contains many bioactive compounds with antioxidant, antiinflammatory, antimicrobial and anti-cancer properties. Fifty-eight bioactive compounds were identified from the methanol extract of $X$. aethiopica fruits including: 2,4,6-octatriene (2.74\%), cyclohexanemethanol $(2.57 \%)$, kaurene (3.59\%), 9, 12-octadecadienoic acid (5.63\%), 1,6-cyclodecadiene (10.81\%), terpineol (3.22\%), cyclohexene $(3.32 \%)$, copaene $(3.04 \%), \quad 1,6-$ 
cyclodecadiene (5.53\%), 1-hexadecyne (5.63\%) and silane (4.63\%) (Okagu et al, 2018). S. hispidus is also used in the traditional treatment of infectious diseases. Antimicrobial tests from the crude extracts of parts of the plant have shown that these extracts inhibit most of the organisms tested: $S$. aureus NCTC 6571, Bacillus subtilis, E. coli NCTC 9001, P. aeruginosa NCTC 6570, Aspergillus niger and Candida (Idowu et al, 2005). P. thonningii is a plant widely used in traditional pharmacopoeia with antibacterial, antifungal, antimalarial, anti-helmintic properties, and methanolic extracts of stem bark exhibited activity against bacterial isolates at a concentration of $20 \mathrm{mg} / \mathrm{ml}$ (Akinpelu et al, 2000; Madara et al, 2010; Kwaji et al, 2010; Asuzu et al, 1991; Agban et al, 2013). P. pinnata is widely used in cosmetology to treat fungal infections and various skin infections (Batawila et al, 2007). P. amarus is also known to have antibacterial, antimycobacterial properties (Bakary et al, 2011; Oluwafemi et al, 2010; Zubair et al, 2017; Babatunde et al, 2014). The different parts of these plants are used in various forms including decoction and maceration as in other studies conducted in Ghana, Ivory Coast, Benin, Cameroon and the parts of the plants used are made up of leaves, barks and roots (Adjet et al, 2016; Bayaga et al 2017; Tsouh et al, 2015). In our study, the method of carbonization and reduction in black powder of parts of selected plants has been widely used by traditional healers. This practice is also adopted in Benin (Yemoa et al, 2008). In Togo, the diagnosis of the disease is made by the difficulty of wound healing and the healers begin the treatment by considering its spiritual dimension and carry out the exorcism by sacrifices to the spirits of the ancestors to promote an effective cure. The treatment continue by the disinfection and wound treatment by herbal remedies. Johnson et al (Johnson et al, 2004) have found in Benin four stages of treatment with a traditional healer, including diagnosis of the disease, removal of necrotic tissue, wound care and exorcism.

Most of the recipes collected in the maritime region consisted of at least two plant species. Several studies of traditional treatments for Buruli ulcer in Africa have highlighted this complexity in the preparation and content of remedies, which rarely include a single plant species (Bayaga et al, 2017). This form of association of various plant species in treatments or recipes could present risks of interaction or toxicity (Yemoa et al, 2008). Several studies have shown positive interactions of these mixtures in inhibiting the in vitro growth of M.ulcerans. A mixture of Zea mays L. and Spigelia anthelmia L. has exhibited a MIC of various concentrations of the extract ranging from 6.25 to $25 \mu \mathrm{g} / \mathrm{mL}$ (Addo et al, 2007). Z. mays is known for it wound healing activity (Sravania et al, 2012). Corn silk is rich in phenolic compounds, especially flavonoids. It also consists of proteins, vitamins, carbohydrates, calcium, potassium, magnesium and sodium salts, volatile oils and steroids such as sitosterol and stigmasterol, alkaloids and saponins (Hasanudin et al 
2012) which could promote healing and the antibacterial activities of the mixture. A mixture of X. aetiopica and C. papaya is also used in Côte d'Ivoire (Adjet et al, 2016) to treat Buruli ulcer. These mixtures offer the advantage of part of their phytochemical composition to promote good healing. Musa paradisiaca is also endowed with a good antimycobacterial activity with a beneficial interaction with several other plant species. Bayaga et al found in Cameroon that the plant was associated with 18 herbal recipes used in the fight against Buruli ulcer (Bayaga et al, 2017). Toxicity studies on most medicinal plants and interactions using animal models have provided results that strengthen their use among humans; however, many such plants could be associated with some toxicity (Nasri et al 2013, Yemoa et al, 2008). This is the case of Carica papaya extracts. The tests on normal human liver cells of it extracts showed a cytotoxicity of 50\%. (Tsouh et al, 2016). Os et al in 2019 have shown that hydroethanolic extracts from leaves of $O$. canum have subacute toxicity in rats treated by oral route (Os et al, 2019). However, some authors emphasize that the actual therapeutic activities of certain medicinal plants cannot be explained by the mere presence of one or other of the constituents. In these mixtures based on extracts of various plants, it is the association or synergy that exists between the constituents, which is very often responsible for the desired effect (Fleurentin et al, 2011). This ethnopharmacological reasoning, which holds a preponderant place in the search for new treatments of tomorrow, puts therefore more and more emphasis on mixtures.

There is therefore a close relationship between these plants and the fight against ulcers in different African cultures. Their use in different cultures attests it. They could have properties and therapeutic potentials related to ulcerations that start with a nodule. The idea of the prohibition accompanies the care in the context of African traditional medicine and in our study the forbidden foods to the patients of Buruli ulcer are identical to those forbidden to the patients in Ivory Coast by the traditional healers (Adjet et al, 2016).

\section{Conclusion}

The treatment of Buruli ulcer uses specific antibiotics that sometimes come up against relapses and therapeutic failures and sometimes the side effects felt by the patients leave sequelae. Thus, other ways of research such as the use of herbal medicine should be explored to improve the management of the disease. Our study has allowed us to identify twenty-six plants, eight of which (B. sapida, $A$. spinosus, $O$. canum, $P$. thonningii, $A$. verra, $A$. occidentale, $P$. pinnata and $X$. aethiopica have a very high Rate of Use. Through the current stage of the results of our study, a collaboration between traditional medicine and modern medicine should be considered for research 
in therapeutic innovation by ethnopharmacological reasoning for chemical and pharmacological evaluation to identify new molecules to treat Buruli ulcer.

\section{Competing interests}

Authors declared they have no conflict of interest.

\section{Authors' contributions}

All the authors contributed to the conduct of this work. The authors of this article have read and approved its content.

\section{Acknowledgements}

The authors thank all the traditional healers of the Maritime Region of Togo for their availability and their collaboration. A special thank to their coordinator Donyo Kossi.

\section{References :}

1. Maman I, Tchacondo T, Kere AB, Piten E, Beissner M, Kobara Y, et al. Risk factors for Mycobacterium ulcerans infection (Buruli Ulcer) in Togo - a case-control study in Zio and Yoto districts of the maritime region. BMC Infectious Diseases. 2018; 18(1):11.

2. Portaels F, Meyers WM, Ablordey A, Castro AG, Chemlal K, de Rijk $\mathrm{P}$, et al. First Cultivation and Characterization of Mycobacterium ulcerans from the Environment. PLoS Negl Trop Diseases. 2008;2(3):e178.

3. Organisation mondiale de la Santé. Agir pour réduire l'impact mondial des maladies tropicales négligées. Genève: OMS; 2010. Report No.: 1.

4. WHO. Treatment of Mycobacterium ulcerans disease (Buruli ulcer): guidance for health workers. 2012.

5. Bretzel G, Huber KL, Kobara B, Beissner M, Piten E, Herbinger K-H, et al. Laboratory Confirmation of Buruli Ulcer Disease in Togo, 20072010. PLoS Negl Trop Diseases. 2011;5(7):e1228.

6. Houngbédji GM, Bouchard P, Frenette J. Mycobacterium ulcerans infections cause progressive muscle atrophy and dysfunction, and mycolactone impairs satellite cell proliferation. Am J Physiol-Regul Integr Comp Physiol. 2011; 300(3):R724-32.

7. Zhang T, Li S-Y, Converse PJ, Grosset JH, Nuermberger EL. Rapid, Serial, Non-invasive Assessment of Drug Efficacy in Mice with Autoluminescent Mycobacterium ulcerans Infection. PLOS Negl Trop Diseases. 2013; 7(12):e2598.

8. Adjet AA, Kouame D, Fokou G. Phytotherapy against buruli ulcer in the Health District of Yamoussoukro (Cote d'Ivoire): Identification, 
description, and symbolic functions of the plants and recipes used. Médecine Santé Trop. 2016 ;(4):408-413.

9. Bayaga HN, Guedje NM, Biye EH. Approche ethnobotanique et ethnopharmacologique des plantes utilisées dans le traitement traditionnel de l'ulcère de Buruli à Akonolinga (Cameroun). Int J Biol Chem Sci. 2017; 11(4):1523-41.

10. Johnson RC, Makoutode M, Hougnihin R, Guedenon A, Ifebe D, Boko $\mathrm{M}$, et al. Le traitement traditionnel de l'ulcère de Buruli au Bénin. Med Trop. 2004;64:145-50.

11. Yemoa A, Gbenou J, Johnson CR, Djego J, Zinsou C, Moudachirou $\mathrm{M}$, et al. Identification et étude phytochimique de plantes utilisées dans le traitement traditionnel de l'ulcère de Buruli au Bénin. Ethnopharmacologia. $2008 ;(42): 48-55$.

12. Yemoa A, Gbenou J, Affolabi D, Moudachirou M, Bigot A, Anagonou $\mathrm{S}$, et al. Beninese Medicinal Plants as a Source of Antimycobacterial Agents: Bioguided Fractionation and In Vitro Activity of Alkaloids Isolated from Holarrhena floribunda Used in Traditional Treatment of Buruli Ulcer. BioMed Research International. 2015;2015:1-5

13. Rapport national sur la diversité biologique du Togo. Lomé, Togo: Ministère de l'environnement et des ressources forestières; 2014 p. 21-4. Report No.: 5.

14. Aburjai T, Hudaib M, Tayyem R, Yousef M, Qishawi M. Ethnopharmacological survey of medicinal herbs in Jordan, the Ajloun Heights region. J Ethnopharmacol. 2007; 110(2):294-304.

15. Tsouh Fokou PV, Nyarko AK, Appiah-Opong R, Tchokouaha Yamthe LR, Addo P, Asante IK, et al. Ethnopharmacological reports on antiBuruli ulcer medicinal plants in three West African countries. Journal of Ethnopharmacology. 2015; 172:297-311.

16. Addo P, Quartey M, Abbas M, Adu-Addai B, Owusu E, Okang I, et al. In-Vitro Susceptibility of Mycobacterium ulcerans to Herbal Preparations. The Internet Journal of Tropical Medicine. 2007; 4(2).

17. Davis R, Donato J, Hartman G, Haas R. Anti-inflammatory and wound healing activity of a growth substance in Aloe vera. Journal of the American Podiatric Medical Association. 1994; 84(2):77-81.

18. Tshilanda DD, Mutwale PK, Onyamboko DVN, Babady PB, Tsalu PV, Tshibangu DST, et al. Chemical Fingerprint and Anti-Sickling Activity of Rosmarinic Acid and Methanolic Extracts from Three Species of Ocimum from DR Congo. J Biosci Med. 2016; 04:59-68.

19. Maia JGS, Andrade EHA, Zoghbi M das GB. Volatile Constituents of the Leaves, Fruits and Flowers of Cashew (Anacardium occidentale L.). Journal of Food Composition and Analysis. 2000; 13(3):227-32. 
20. Kubo I, Nihei K, Tsujimoto K. Antibacterial Action of Anacardic Acids against Methicillin Resistant Staphylococcus aureus (MRSA). J Agric Food Chem. 2003; 51(26):7624-8.

21. Gonçalves GMS, Gobbo J. Antimicrobial effect of Anacardium Occidentale extract and cosmetic formulation development. Brazilian Archives of Biology and Technology. déc 2012;55(6):843-50.

22. Akinjogunla OJ, Adenugba IT, Jumbo OM. In-vitro antibacterial evaluation of ethanolic stem crude extracts of Anacardium occidentale L. (Anacardiaceae) on Streptococcus mutans associated with dental caries. Sci J of Microb. 2012; 1(3):71-81.

23. Saidu A., Akanya H., Dauda BE., Ogbadoyi E. Antibacterial and comparative hypoglycemic effect of Anacardium occidentale leaves. Inter Res J of Bioch and Bioin. 2012; 2(1):6-10.

24. Marques M, Albuquerque L, Xavier-Filho J. Antimicrobial and insecticidal activities of cashew tree gum exudate. Annals of Applied Biology. 1992; 121(2):371-7.

25. Laurens A, Mboup S, Giono-Barber p, Sylla O, David-Prince M. étude de l'action antibactérienne d'extraits d'Anacardium occidentale L. 1982;40:143-6.

26. Silva RA da, Liberio SA, Amaral FMM do, Nascimento FRF do, Torres LMB, Neto VM, et al. Antimicrobial and Antioxidant Activity of Anacardium occidentale L. Flowers in Comparison to Bark and Leaves Extracts. Journal of Biosciences and Medicines. 2016; 04:87-99.

27. Okagu IU, Ngwu UE, Odenigbo CJ. Bioactive Constituents of Methanol Extract of Xylopia aethiopica (UDA) Fruits from Nsukka, Enugu State, Nigeria. Open Access Library Journal. 2018; 05:11.

28. Idowu PA, Moody JO, Odelola HA. Phytochemical and antimicrobial screening of three Nigerian medicinal plants used to treat infectious diseases traditionally. Journal of Pharmacy \& Bioresources. 1 janv 2005; 2(2):116-9.

29. Akinpelu DA, Obuotor EM. Antibacterial activity of Piliostigma thonningii stem bark. Fitoterapia. 2000; 71(4):442-3.

30. Madara AA, Ajayi JA, Salawu OA, Tijani AY. Anti-malarial activity of ethanolic leaf extract of Piliostigma thonningii Schum. (Caesalpiniacea) in mice infected with Plasmodium berghei berghei. Afr J of Biotech. 2010; 9(23):3475-80.

31. Kwaji A, Bassi PU, Aoill M, Nneji CM, Ademowo G. Preliminary studies on Piliostigma thonningii Schum leaf extract: Phytochemical screening and in vitro antimalarial activity. Afr J Microbiol Res. 2010; 4(9):735-9. 
32. Asuzu I, Gray A, Waterman P. The anthelmintic activity of D-3-Omethylchiroinositol isolated from Piliostigma thonningii stem bark. Fitoterapia. 1999; 70:77-9.

33. Agban A, Gbogbo K, Hoekou YP, Atchou K, Tchacondo T, Batawila $\mathrm{K}$, et al. Evaluation de l'activité antifongique des extraits de Cassia alata L. et de Piliostigma thonningii (Schumach.) Milne Redh. (Fabaceae) sur Candida albicans. Int $J$ Biol Chem Sci. 2013;7(3):1041-7.

34. Batawila K, Tossou GM, Gbogbo KA, Wala K, Akpavi S, Dourma M, et al. Activites antifongiques de Paullinia pinnata L. (Sapindaceae) et Pergularia daemia (forssk.) Chiov. (Asclepiadaceae), deux plantes à usages cosmetologique et dermatologique. J Rech Sci Univ Lomé. 2007;9(1):83-9.

35. Bakary C, Raymond NK, N'guetta A, Euloge E, Coulibaly ND, Nöel $\mathrm{T}$, et al. Activité anti-mycobactérienne in vitro des extraits de Phyllanthus amarus (Schum et Thonn) sur les souches de Mycobacterium ulcerans en Côte d'Ivoire. Bull Société R Sci Liège. 2011;80:759-71.

36. Oluwafemi F, Debiri F. Antimicrobial Effect of Phyllanthus amarus and Parquetina nigrescens on Salmonella typhi. Afr J Biomed Res. 2010; 11(2):215 - 219 .

37. Zubair MF, Atolani O, Ibrahim SO, Adebisi OO, Hamid AA, Sowunmi RA. Chemical constituents and antimicrobial properties of Phyllanthus amarus (Schum \& Thonn). J Pure Appl Sci. 2017; 10(1):238-46.

38. Babatunde SK, Abubakare AA, Abdulraheem YJ, Ajiboye EA. Antimicrobial activity of Phyllanthus amarus on some human intestinal facultatively anaerobic flora. Int J Med Biomed Res. 2014; 3(1):52-7.

39. Fleurentin J, Weniger B, Bourdy G. Traditions thérapeutiques et médicine de demain. Les enjeux de l'ethnopharmacologie. Ouest France.2011. $126 \mathrm{p}$.

40. WHO. Global Health observatory data repository Buruli Ulcer. http://apps.who.int/gho/data. 2019.

41. Lakouéténé DPB, Ndolngar G, Berké B, Moyen J-M, KoshKomba E, Zinga I, Silla S, Millogo- Rasolodimby J, Vincendeau P, Syssa-Magalé L-L, Nacoulma-Ouedraogo OG, Laganier R, Badoc A, Chèze C, 2009. Enquête ethnobotanique des plantes utilisées dans le traitement du paludisme à Bangui. Bull Soc Pharm Bord 148: 123-38.

42. Hasanudin K, Hashim P, Mustafa S. Corn Silk (Stigma Maydis) in Healthcare: A Phytochemical and Pharmacological Review. Molecules. 13 août 2012;17(8):9697-715. 
43. Nasri H, Shirzad H. Toxicity and safety of medicinal plants. Journal of HerbMed Pharmacology. 2013;2(2):21-2.

44. Tsouh Fokou P, Kissi-Twum A, Yeboah-Manu D, Appiah-Opong R, Addo P, Tchokouaha Yamthe L, et al. In Vitro Activity of Selected West African Medicinal Plants against Mycobacterium ulcerans Disease. Molecules. 2016;21(4):445.

45. Os J. Sub-acute toxicity study of ethanol leaf extract of Ocimum canum on the kidney of wistar rats. African Journal of Pharmaceutical Research \& Development. 2019;11(1):8. 